\title{
Feasibility of soybean cultivation technology in rainfed area with acidic soil in Lampung
}

\author{
Dian Adi Anggraeni Elisabeth*, Agustina Asri Rahmianna, Arief Harsono, and Erliana \\ Ginting \\ Indonesian Legumes and Tuber Crops Research Institute (Iletri), Jalan Raya Kendalpayak Km 8. \\ Malang, East Java 65101, Indonesia
}

\begin{abstract}
In 2017, Indonesian Legumes and Tuber Crops Research Institute (Iletri) introduced a package of soybean cultivation technology in rainfed area with non-acidic soil in Maros, South Sulawesi named Biodetas which was able to produce the yield of 2.1-3.2 t/ha. In 2018, Biodetas was developed to East Lampung, Lampung which has specific rainfed area with acidic soil. Therefore, the technology has been modified by the addition of dolomite and named as "specific Biodetas". To finding out the results of "specific Biodetas" application in improving soybean productivity and farmers' income, there are three treatments involved: P1 = Doing tillage and planting with manual dibbling tool, P2 = Doing tillage and planting with simple planting tool, and P3 = No tillage and planting with simple planting tool. P2 and P3 were specific Biodetas adjusting to the existing farmers' cultivation. The yield of specific Biodetas were 1.362-1.727 t/ha. P3 produced the highest yield and the highest total benefit of IDR 6,670,500/ha. The specific Biodetas adjusting to the existing farmers' cultivation could provide additional benefit of IDR 640,000 for P2 and IDR 3,706,000 for P3. MBCR values of $\mathrm{P} 2$ and $\mathrm{P} 3$ were 3.64 and 4.92, respectively, reflected that the technologies were feasible to be applied.
\end{abstract}

\section{Introduction}

The low national soybean production in meeting domestic market demand requires various efforts to minimize the gap between national production and import. The efforts include intensification in center of soybean production, extensification and diversification based on existing resources potential [1]. The expanding of soybean planting areas in Indonesia is currently directed at many potential lands, one of which is rainfed areas [2]. Non-irrigated paddy field area in Lampung Province including rainfed areas reaches 172,169 ha, 5.1\% of the total non-irrigated paddy field area in Indonesia [3]. The main problems of crops planting in rainfed areas are limited water availability [4] and low farmers' interest to cultivate soybean due to the profit is lower than other food crops' profit [5]. Due to the limited water availability and the very low competitiveness of soybean when compared to corn, most of the rainfed areas in Lampung have not been utilized to cultivate soybean after the rice harvest. The

\footnotetext{
*Corresponding author: dian.elisabeth21@gmail.com
} 
cropping pattern in rain fed areas widely applied by farmers is paddy-corn or paddymungbean, and even paddy-fallow depending on water availability.

Soybean productivity in Lampung is relatively low, i.e. $1.16 \mathrm{t} / \mathrm{ha}$. It is even lower than the average of national soybean productivity of $1.57 \mathrm{t} / \mathrm{ha}$ [6]. Some studies show the low productivity of soybean cultivated in some rainfed areas which reaching 1.4-2.4 t/ha depend on the use of improved soybean varieties and production inputs given. The productivity of Grobogan variety in Central Java is 1.4-2.4 t/ha [7], Demas 1 is $1.75 \mathrm{t} / \mathrm{ha}$ and Devon 2 is 1.8 $\mathrm{t} /$ ha in South Sulawesi [8], meanwhile the potential yield of those improved soybean varieties is more than $2.5 \mathrm{t} / \mathrm{ha}$ [9].

Most of acidic dry lands in Lampung have characteristics of poor macro and micro biotic nutrient as well as high Al saturation level. They require high dosage of organic and chemical fertilizers for high soybean yield [10]. Some studies related to the application of soybean cultivation technology components in acidic dry land of Lampung have been carried out. The Indonesian Center for Agricultural Technology Assessment and Development [BBP2TP] (2008) recorded that the application of soybean cultivation technology including land preparation, the use of Anjasmoro variety, fertilization of $75 \mathrm{~kg}$ Urea $+100 \mathrm{~kg}$ SP $36+100$ $\mathrm{kg} \mathrm{KCl}$ and 1,500 $\mathrm{kg}$ dolomite per ha, the use of insecticides and seed treatment, as well as weeding results an average yield of $1.47 \mathrm{t} / \mathrm{ha}$ (unpublished data). In acidic dry land of Central Lampung, the application of $500-1,500 \mathrm{~kg} / \mathrm{ha}$ manure combined with $150-600 \mathrm{~kg} / \mathrm{ha}$ ameliorant can provide soybean yield more than $2.0 \mathrm{t} / \mathrm{ha}$ [11].

Several technical and social economic problems of soybean cultivation in rainfed area related to water limitation and low farmers' interest can be overcome by increasing soybean productivity and decreasing production cost thereby increasing the profit of soybean farming. To support the national program in soybean production improvement, the Indonesian Agency for Agricultural Research and Development (IAARD) through Iletri has set up package of soybean cultivation technology in rainfed area named Biodetas. In 2017, the application of Biodetas in Tompobulu Sub-district, Maros Regency, South Sulawesi Province which has non-acidic soil type is able to produce 2.1-3.2 t/ha soybean seeds [12]. Components of Biodetas in Maros include the application of (1) bio-fertilizer, (2) the lower dosage of Nitrogen-Phosphorus-Potassium (NPK) fertilizer from the existing one, (3) foliar fertilizer, and (4) organic fertilizer [13]. Biodetas in Maros Regency then referred to as recommended Biodetas because it is used as a basic soybean cultivation technology in rainfed area which will then be developed to other rainfed areas adjusting to their specific agro-ecosystem conditions. Biodetas needs to be disseminated more broadly by giving attention to the specific agro-ecology of soybean cultivation in order to be immediately adopted and developed at farmer level. Rainfed area in Lampung has a specific condition of acidic soil which can be an obstacle to soybean growth. Therefore, it is needed a soybean cultivation technology package more specifically for acidic soil in order to optimize the growth of soybean crops.

The paper is written to find out the results of the introduction and application of soybean cultivation technology package of Biodetas in specific rainfed area with acidic soil of Lampung Province in improving soybean productivity and farmers' income.

\section{Materials and methods}

The research was conducted in East Lampung Regency, Lampung Province, Indonesia in the planting season of May-August 2018. The study involved 47 farmers with a total area of 33 ha in Raman Utara Sub-district. The application of soybean cultivation technology package of Biodetas in rainfed area was developed adapting to specific agro-ecology of East Lampung Regency with its acidic soil. The technological package experienced a slight modification from the recommended Biodetas of Maros Regency with the addition of dolomite, as can be seen in Table 1, and named as specific Biodetas. 
Table 1. Soybean cultivation technology packages of Biodetas in rainfed areas with non-acidic and acidic soils, Iletri, 2017-2018.

\begin{tabular}{|c|c|c|}
\hline \multirow[b]{2}{*}{$\begin{array}{l}\text { Technology } \\
\text { components }\end{array}$} & \multicolumn{2}{|c|}{ Soybean cultivation technology packages of } \\
\hline & $\begin{array}{l}\text { Recommended Biodetas }^{1} \text { (in non- } \\
\text { acidic soil) - Maros Regency, } \\
\text { South Sulawesi } 2017\end{array}$ & $\begin{array}{c}\text { Specific Biodetas (in acidic soil) - } \\
\text { East Lampung Regency, } \\
\text { Lampung } 2018\end{array}$ \\
\hline Tillage & $\begin{array}{l}\text { No tillage; straws are cut } 1-3 \mathrm{~cm} \\
\text { above the ground, spread as mulch }\end{array}$ & $\begin{array}{l}\text { Tillage; straws are cut } 1-3 \mathrm{~cm} \text { above } \\
\text { the ground, spread as mulch }\end{array}$ \\
\hline Drainage channels & $\begin{array}{c}\text { Made every 3-4 m; width and } \\
\text { depth of channels are about } 30 \mathrm{~cm}\end{array}$ & $\begin{array}{l}\text { Made every 3-4 m; width and depth } \\
\text { of channels are about } 30 \mathrm{~cm}\end{array}$ \\
\hline Pre-grown herbicide & Applied 2-3 days before planting & Applied 20-21 days after planting \\
\hline Seed preparation & $\begin{array}{c}\text { Use quality seeds; } \\
\text { growth viability }>80 \%\end{array}$ & $\begin{array}{c}\text { Use quality seeds; } \\
\text { growth viability }>80 \%\end{array}$ \\
\hline Number of seeds & $2-3$ seeds/hole & $1-3$ seeds/hole \\
\hline Improved variety & Anjasmoro & Anjasmoro \\
\hline Planting time & 4-7 days after rice harvesting & 4-7 days after rice harvesting \\
\hline Planting method & Use manual dibbling tool & Use manual dibbling tool \\
\hline Plant spacing & $40 \mathrm{~cm} \mathrm{x} 15 \mathrm{~cm}$ & $40 \mathrm{~cm} \times 20 \mathrm{~cm}$ \\
\hline Seed treatment & $\begin{array}{l}\text { Agrisoy } 200 \mathrm{~g} / 50 \mathrm{~kg} \text { of seed } / \mathrm{ha} \\
\text { mixed with wet seeds before } \\
\text { planting }\end{array}$ & $\begin{array}{l}\text { Agrisoy } 200 \mathrm{~g} / 50 \mathrm{~kg} \text { of seed } / \mathrm{ha} \\
\text { mixed with wet seeds before } \\
\text { planting }\end{array}$ \\
\hline NPK fertilizer & $\begin{array}{c}200 \mathrm{~kg} / \mathrm{ha} \text { Phonska }+ \\
50 \mathrm{~kg} / \mathrm{ha} \mathrm{SP} 36\end{array}$ & $\begin{array}{c}200 \mathrm{~kg} / \mathrm{ha} \text { Phonska }+ \\
50 \mathrm{~kg} / \mathrm{ha} \mathrm{SP} 36\end{array}$ \\
\hline Dolomite & - & $500 \mathrm{~kg} / \mathrm{ha}$ \\
\hline Foliar fertilizer & $\begin{array}{c}\text { Sprayed } 20 \text { and } 40 \text { days after } \\
\text { planting }\end{array}$ & - \\
\hline Organic fertilizer & $\begin{array}{c}1,000 \mathrm{~kg} / \mathrm{ha} \text { as a cover for planting } \\
\text { holes }\end{array}$ & $\begin{array}{c}1,000 \mathrm{~kg} / \mathrm{ha} \text { as a cover for planting } \\
\text { holes }\end{array}$ \\
\hline $\begin{array}{l}\text { Pests and diseases } \\
\text { controlling }\end{array}$ & $\begin{array}{l}\text { IPM, sprayed with chemical } \\
\text { pesticides }\end{array}$ & $\begin{array}{l}\text { IPM, sprayed with chemical } \\
\text { pesticides }\end{array}$ \\
\hline Irrigation & $\begin{array}{c}\text { Once; at around } 20 \text { days after } \\
\text { planting }\end{array}$ & Depend on rainfall \\
\hline Harvesting & At physiological mature stage & At physiological mature stage \\
\hline Post harvesting & Thresher & Thresher \\
\hline
\end{tabular}

The application of specific Biodetas in acidic soil adjusting to the existing farmers' soybean cultivation so that there were three treatments for the specific Biodetas package, particularly at the stage of tillage and planting method, namely: (1) P1 = doing tillage and using manual dibbling tool, (2) P2 = tillage and using simple planting tool; and (3) P3 = no tillage and using simple planting tool. The simple planting tool is equipped with a tool for making planting hole and a tool for placing seeds in the planting hole (Figure 1). 


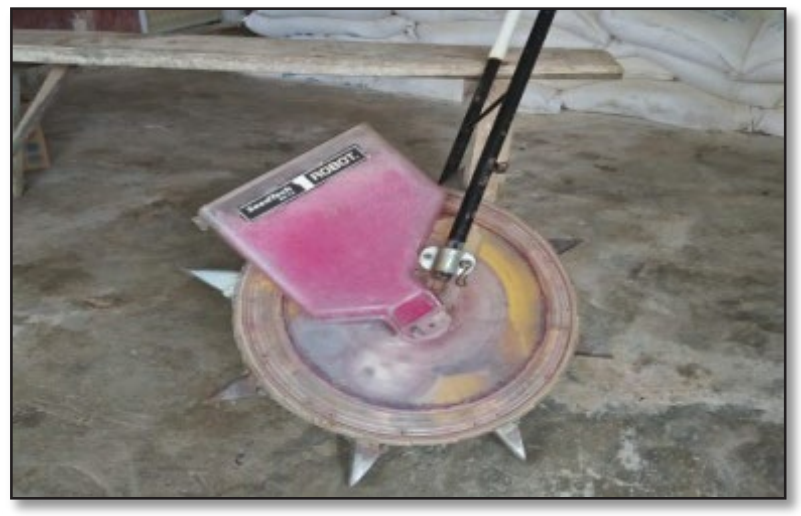

Fig. 1. Simple planting tool used by farmers in East Lampung Regency, Lampung Province

Parameters observed included average yield and harvested-seed moisture content, average yield at $15 \%$ moisture content, production cost, farming income and financial profitability of specific Biodetas package application employing the benefit cost ratio $(\mathrm{B} / \mathrm{C}$ ratio) approach with the following equation [14]:

$$
B / C \text { ratio }=\frac{(Q \times P)-(V C+F C)}{T V C}
$$

Where, $\mathrm{B} / \mathrm{C}$ ratio $=$ benefit cost ratio; $\mathrm{Q}=$ production $(\mathrm{kg} / \mathrm{ha} /$ season $) ; \mathrm{P}=$ selling price $(\mathrm{IDR} / \mathrm{kg}) ; \mathrm{VC}=$ variable cost $(\mathrm{IDR}) ; \mathrm{FC}=$ fixed cost $(\mathrm{IDR}) ; \mathrm{TVC}=$ total cost (IDR/ha/season).

$\mathrm{B} / \mathrm{C}$ ratio is used to measure the feasibility of farming by comparing the total benefit with the total production cost [15]. The analysis results of $\mathrm{B} / \mathrm{C}$ ratio are as follows: $\mathrm{B} / \mathrm{C}$ ratio $>1$, specific Biodetas package is profitable; $\mathrm{B} / \mathrm{C}$ ratio $=1$, specific Biodetas package is at the break-even point; and $\mathrm{B} / \mathrm{C}$ ratio $<1$, specific Biodetas package is not profitable.

The technological feasibility for changing the specific Biodetas introduced by Iletri to the specific Biodetas adjusting to the existing farmers' soybean cultivation measured by gains and losses method and partial analysis of technological changing feasibility employing marginal benefit cost ratio (MBCR) approach with the following equation [14]:

$$
M B C R=\frac{T R a-T R b}{T C a-T C b}
$$

Where, $\mathrm{MBCR}=$ marginal benefit cost ratio; $\mathrm{TRa}=$ total revenue when implementing specific Biodetas adjusting to the existing farmers' cultivation (IDR); TRb = total revenue when implementing specific Biodetas introduced by Iletri (IDR); $\mathrm{TCa}=$ total production cost when implementing specific Biodetas adjusting to the existing farmers' cultivation (IDR); $\mathrm{TCb}=$ total production cost when implementing specific Biodetas introduced by Iletri (IDR).

To cover the costs of depreciation, transportation, and other costs, the MBCR calculation should include elements of risk premium up to $90 \%$ [14]. Therefore, the value of MBCR should be greater than 1.9 to indicate that changing specific Biodetas introduced by Iletri to the specific Biodetas adjusting to the existing farmers' soybean cultivation is feasible to be applied by farmers. 


\section{Results and discussion}

\subsection{Application of specific Biodetas in rainfed area with acidic soil}

The soybean cultivation commonly practiced by farmers in Lampung were (1) no tillage, which straws are cut near the surface of the land; (2) irrigation channels are made in the edge of the plot or in each beds with the width of 4-5 m; (3) traditionally planting method uses manual dibbling tool with spacing of $25 \mathrm{~cm} \times 25 \mathrm{~cm}$ or $30 \mathrm{~cm}$ x $30 \mathrm{~cm}$ with $2-3$ seeds per hole; (4) the fertilizers applied are $50 \mathrm{~kg} / \mathrm{ha}$ Urea and $100 \mathrm{~kg} / \mathrm{ha}$ NPK Phonska at 14 days after planting; (5) the irrigation water is only given when the crops are highly affected by drought; (6) weeds are manually controlled with both pre and post-growth herbicides; (7) pests are controlled, however farmers are often late in controlling pod sucking or borer pests due to their lack of understanding on pest control; (8) mostly of post harvesting uses manual method even though in some areas already use threshers. The doses of fertilizers in recommended Biodetas and specific Biodetas are higher than commonly farmers' use. The use of high doses fertilizers with more diverse kind of fertilizers are caused by the characteristics of irrigation in rainfed area which are actually unfavorable for food crops. Therefore, the doses of fertilizers should be adjusted to the need of the crops during its growth period in order to increase the yields [16].

The application of specific Biodetas in rainfed area with acidic soil in East Lampung Regency was adjusted to the existing farmers' soybean cultivation. According to the cooperator farmers, doing their own usual soybean cultivation give a satisfaction and confidence for farmers. The model of technology transfer conducted in East Lampung is called as farmer participatory model [17]. Farmers are actively involved from the beginning until the end of the study process so that the scientific side of study is enriched and its success can be improved. The study of [18] shows that to accelerate agricultural innovation in specific agro-ecology, it is necessary to build a bottom-up planning model in which farmers are involved in the preparation of innovation. It ultimately affects the suitability of innovation with the needs of farmers and the specific agro-ecosystem as well as triggers effective communication during the learning process.

Even though most of farmers in East Lampung Regency still do tillage, some cooperator farmers do not do tillage due to its high cost which is not comparable with the yield of soybean. Some cooperator farmers have used simple planting tool (Figure 1) instead of manual dibbling tool with the reason to minimize the planting cost. Therefore, in the introduction of specific Biodetas, three treatments were used involved (1) doing tillage and using manual dibbling tool carried out by $64 \%$ of cooperator farmers, (2) doing tillage and using simple planting tool by $32 \%$ of cooperator farmers; and (3) no tillage and using simple planting tool by $4 \%$ of cooperator farmers. The second and the third treatments were specific Biodetas adjusting to the existing farmers' cultivation.

\subsection{Soybean productivity of specific Biodetas in rainfed area with acidic soil}

Moisture content of harvested-soybean seeds varied in the range of $11.5 \%$ to $14.1 \%$, which indicated that the seeds produced by farmers were generally dry and in safe condition for storage. The moisture content has been in accordance with the Indonesian national standard (SNI 01-3922 -1995) for soybean i.e. maximum 14\%, and can reach $16 \%$ as maximum moisture content for the 4th grade quality of soybean [19]. The range of soybean yields obtained were 1.362-1.727 t/ha (Table 2). However, the yield is still below the potential yield of Anjasmoro i.e. 2.03-2.25 t/ha [9]. P3 treatment produced the highest yield i.e. 1,727 t/ha or reached $76-85 \%$ of the Anjasmoro's potential yield. Anjasmoro has some advantages which one of them is its quite good adaptability in various agro-ecosystems so that this 
soybean variety is widely developed and cultivated by farmers on dry land, rainfed, swamp land, and tidal land [20].

Soybean yield produced by cooperator farmers was categorized as stock-seeds (SS) class. From a total area of 33 ha, the total production obtained with a moisture content of $15 \%$ was 60.8 tons. In the field, around 22.8 tons $(41.7 \%)$ of the seeds were purchased by a local seed breeding business as a partner of the Lampung Provincial Agricultural Office for distributing seeds and other agricultural inputs to farmers related to the agricultural programs. Assuming that all those stock seeds of 22.8 tons are distributed and cultivated by farmers, with the need of seeds per hectare is $50 \mathrm{~kg}$, the availability of seeds can meet 456 ha of soybean planting area. The stock-seeds (SS) class can be cultivated and harvested as the extension-seeds (ES) class in the next planting season.

Table 2. Performance of Anjasmoro productivity.

\begin{tabular}{|c|c|c|c|}
\hline $\begin{array}{c}\text { Performance of soybean } \\
\text { productivity }\end{array}$ & P1 & P2 & P3 \\
\cline { 2 - 4 } & 1.311 & 1.423 & $\mathbf{1 . 7 1 0}$ \\
\hline $\begin{array}{c}\text { Average yield (t/ha) } \\
\text { Harvested-seed moisture content } \\
\text { (\%) }\end{array}$ & 11.5 & 11.9 & $\mathbf{1 4 . 1}$ \\
\hline $\begin{array}{c}\text { Average yield at 15\% moisture } \\
\text { content (t/ha) }\end{array}$ & 1.362 & 1.398 & $\mathbf{1 . 7 2 7}$ \\
\hline
\end{tabular}

\subsection{Soybean productivity of specific Biodetas in rainfed area with acidic soil}

The production inputs costs for the three treatments were the same due to the kind and the amount of production inputs provided i.e. soybean seed, fertilizers (bio, inorganic, and organic), chemical pesticides and others were adjusted to the need of production inputs as the recommended Biodetas package. The addition of dolomite for soybean cultivation in rainfed area with acidic soil for the specific Biodetas package increased production cost by IDR $625,000 /$ ha when compared to the recommended Biodetas package that was previously applied in South Sulawesi. 
Table 3. Production cost of specific Biodetas.

\begin{tabular}{|c|c|c|c|}
\hline \multirow{2}{*}{$\begin{array}{c}\text { Components of production } \\
\text { cost }\end{array}$} & $\mathbf{3}$ & Treatment of \\
\cline { 2 - 4 } Production inputs cost (IDR) & & & P3 \\
\hline Soybean seed & 600,000 & 600,000 & 600,000 \\
\hline Biofertilizer (Agrisoy) & 30,000 & 30,000 & 30,000 \\
\hline Inorganic fertilizer & & & 520,000 \\
\hline a. Phonska & 520,000 & 520,000 & 125,000 \\
\hline b. SP36 & 125,000 & 125,000 & $1,000,000$ \\
\hline Organic fertilizer & $1,000,000$ & $1,000,000$ & 625,000 \\
\hline Dolomite & 625,000 & 625,000 & 890,000 \\
\hline Pesticides, fungicides, etc & 890,000 & 890,000 & $\mathbf{3 , 7 9 0 , 0 0 0}$ \\
\hline Production inputs cost (A) & $\mathbf{3 , 7 9 0 , 0 0 0}$ & $\mathbf{3 , 7 9 0 , 0 0 0}$ & 400,000 \\
\hline Labors cost (IDR) & & & 400,000 \\
\hline Tillage & $1,200,000$ & $1,200,000$ & 180,000 \\
\hline Planting & 600,000 & 400,000 & 160,000 \\
\hline Fertilizing & 180,000 & 180,000 & 480,000 \\
\hline Pests and diseases controlling & 160,000 & 160,000 & 600,000 \\
\hline Weeding & 480,000 & 480,000 & 140,000 \\
\hline Harvesting & 600,000 & 600,000 & $1,087,800$ \\
\hline Postharvesting & 140,000 & 140,000 & 77,700 \\
\hline Processing & 858,200 & 880,600 & $\mathbf{3 , 5 2 5 , 5 0 0}$ \\
\hline Yield transportation & 61,300 & 62,900 & $\mathbf{7 , 3 1 5 , 5 0 0}$ \\
\hline Labors cost (B) & $\mathbf{4 , 2 7 9 , 5 0 0}$ & $\mathbf{4 , 1 0 3 , 5 0 0}$ & \\
\hline Total production cost (A+B) & $\mathbf{8 , 0 6 9 , 5 0 0}$ & $\mathbf{7 , 8 9 3 , 5 0 0}$ & \\
\hline
\end{tabular}

The differences in labors cost were particularly for tillage and planting stages. P1 treatment required the highest labors cost, $2.2 \%$ higher than P2 treatment and $9.3 \%$ higher than P3 (Table 3). Farmers could reduce labors cost by $66.7 \%$ by not doing tillage and by $33.3 \%$ by planting using simple planting tool. Other labors cost varied were the costs of processing and yield transportation. Both of them were highly depend on soybean yield obtained by farmers. In the processing stage, threshing cost must be spent by farmers was IDR 700,000 for every ton of soybean. The yield transportation cost spent by farmers to transport the crops yield from the harvested area to the location of local seed breeding business was IDR 50,000 for every ton of soybean.

\subsection{Farming income and financial profitability of specific Biodetas}

With the soybean price received from local seed breeding business was IDR 9,000/kg in August 2018, the highest total revenue received by farmers was obtained by P3 treatment, which was $126.8 \%$ and $123.5 \%$ higher than P1 and P2 treatments, respectively. With the total production cost for each treatment varied (Table 4), where the lowest was P3 treatment followed by $\mathrm{P} 2$ and $\mathrm{P} 1$, so that the total benefit was also varied. The lowest total benefit was P1 treatment and the highest was P3. The adjusting of P1 treatment with existing farmers' cultivation increased the benefits of $\mathrm{P} 2$ and $\mathrm{P} 3$ respectively by $115.7 \%$ and $225.0 \%$ compared to $\mathrm{P} 1$. The result of financial profitability analysis showed that the three treatments have not been able to provide benefits to soybean farming, as reflected by the values of $\mathrm{B} / \mathrm{C}$ ratio that less than 1 (Table 4). 
Table 4. Farming income and financial profitability of specific Biodetas.

\begin{tabular}{|c|c|c|c|}
\hline \multirow{2}{*}{ Components } & \multicolumn{3}{|c|}{ Treatment of } \\
\cline { 2 - 4 } & P1 & P2 & P3 \\
\hline Production cost (IDR) & & & $3,790,000$ \\
\hline a. Production materials & $3,790,000$ & $3,790,000$ & $3,525,500$ \\
\hline b. Labors & $4,279,500$ & $4,103,500$ & $7,315,500$ \\
\hline Total production cost (IDR) & $8,069,500$ & $7,893,500$ & 1,727 \\
\hline Total production (kg)* & 1,362 & 1,398 & 1,554 \\
\hline Net production (kg)** & 1,226 & 1,258 & $4,707.53$ \\
\hline $\begin{array}{c}\text { Production cost/kg seed } \\
\text { (IDR/kg) }\end{array}$ & $6,581.97$ & $6,279.87$ & $13,986,000$ \\
\hline Total revenue (IDR)*** & $11,034,000$ & $11,322,000$ & $6,670,500$ \\
\hline Total benefit (IDR) & $2,964,500$ & $3,428,500$ & 0.91 \\
\hline B/C ratio & 0.37 & 0.43 & \\
\hline
\end{tabular}

Notes:

* Total production is the yield of soybean at $15 \%$ moisture content

** Net production is the yield of soybean after reduced by $10 \%$ losses during threshing

$* * *$ Total revenue is the result of net production multiplied by the selling price of soybean received from local seed breeding business in August 2018 i.e. IDR 9,000/kg

\subsection{Technological feasibility for changing specific Biodetas}

Evaluation of technological feasibility for changing the specific Biodetas introduced by Iletri to the specific Biodetas adjusting to the existing farmers' soybean cultivation using the gains and losses method in Table 5 showed that the specific Biodetas adjusting to the existing farmers' soybean cultivation of P2 treatment could decrease the cost structure of IDR 176,000 /ha from P1 treatment. P3 treatment even could decreased the cost structure by IDR $754,000 /$ ha from P1 treatment. Changes in the cost structure for P2 against P1 were caused by the decrease of labor costs for planting, processing, and yield transportation. For P3 against $\mathrm{P} 1$, the change of cost structure was added by the decrease of labor cost for tillage reaching $66.7 \%$.

Table 5. Technological feasibility for changing of specific Biodetas combined with common farmers practises.

\begin{tabular}{|c|c|c|c|}
\hline Lossess & Amount (IDR) & Gains & Amount (IDR) \\
\hline \multicolumn{4}{|c|}{ P2 against P1 } \\
\hline Cost of planting & $(200,000)$ & $\begin{array}{c}\text { Additional farming } \\
\text { revenue }\end{array}$ & 464,000 \\
\hline Cost of processing & 22,400 & & \\
\hline Cost of yield transportation & 1,600 & & 464,000 \\
\hline Total losses & $(176,000)$ & & \\
\hline Additional benefit & 640,000 & & $2,952,000$ \\
\hline MBCR & 3.64 & & \\
\hline \multicolumn{5}{|c|}{ P3 against P1 } & \\
\hline Cost of land preparation & $(800,000)$ & $\begin{array}{c}\text { Additional farming } \\
\text { revenue }\end{array}$ & \\
\hline Cost of planting & $(200,000)$ & & $2,952,000$ \\
\hline Cost of processing & 229,600 & & \\
\hline Total losses & $(754,000)$ & & \\
\hline Additional benefit & $3,706,000$ & & \\
\hline MBCR & 4.92 & & \\
\hline
\end{tabular}

Notes:

* Numbers in parentheses indicate negative values 
The decreases in cost structure were contributed to the additional benefits obtained by farmers. The additional benefits obtained from the changing P1 treatment into P2 was IDR $640,000 /$ ha in one planting season while the changing P1 treatment into P3 was IDR 3,706,000/ha. The MBCR of P2 against P1 and P3 against P1 were 3.64 and 4.92, respectively. The values of MBCR meant that every IDR 1,000 addition to the production cost is able to increase the revenues of IDR 3,640 and IDR 4,920. The values of MBCR reflected the specific Biodetas adjusting to the existing farmers' soybean cultivation were feasible to be applied.

\section{Conclusion and recommendation}

The soybean yield of the specific Biodetas package in acidic soil of Lampung was lower than the recommended Biodetas package in non-acidic soil of South Sulawesi. The specific agroecological condition may affect the yield. The specific Biodetas introduced by Iletri have not been able to provide financial benefits for farmers yet. However, when adjusting to the existing farmers' soybean cultivation, the specific Biodetas application provided higher financial benefit values of $115.7-225.0 \%$ than the application of specific Biodetas introduced by Iletri. The application of the specific Biodetas adjusting to the existing farmers' soybean cultivation i.e. without tillage and planting using simple planting tool was the most financially profitable and technologically feasible for further application in East Lampung, Lampung.

Acknowledgement. We thank Ponirin and Sugiyono for technical assistance in the field during this study. We also extend our gratitude to the Indonesian Agency for Agricultural Research and Development (IAARD), the Ministry of Agriculture for funding the research.

\section{References}

1. A. G. Tahir, D. H. Darwanto, J. H. Mulyo, Jamhari, Jurnal Agro Ekonomi 28, 133 (2010)

2. N. E. Faizati, A. Rifin, N. Tinaprilla, AGRARIS Journal of Agribusiness and Rural Development Research 2, 97 (2016)

3. Statistics Indonesia [BPS], Land area by utilization 2014, in Statistics Indonesia. Jakarta, Indonesia (2014)

4. H. Kuswantoro, Pertanika J. Trop.Agric. Sc. 41, 1261 (2018)

5. A. K. Zakaria, Analisis Kebijakan Pertanian 8, 259 (2010)

6. Statistics Indonesia [BPS], Statistik dasar luas panen dan produktivitas kedelai, 19932015, in https://www.bps.go.id (2016)

7. B. Nuswantara, T. M. Prihtanti, D. R. V. Suprihati, H. J. Nadapdap, Proceedings of Unri Conference Series: Agriculture and Food Security Vol. 1, 26 September 2019, Pekanbaru, Indonesia (2019)

8. H. Gunady, M. Djunaidy, Jurnal Panrita Abdi 3, 70 (2019)

9. Iletri, Deskripsi varietas unggul kedelai (1918-2016), in http://balitkabi.litbang.pertanian.go.id/wp-content/uploads/2016/09/kedelai.pdf (2016)

10. A. Harsono, Prihastuti, Subandi, Iptek Tanaman Pangan 6, 57 (2011)

11. Sudaryono, A. Wijanarko, Suyamto, Jurnal Penelitian Pertanian Tanaman Pangan 30, 43 (2011)

12. D. A. A. Elisabeth, A. Harsono, T. Sundari, N. Nugrahaeni, Jurnal Pengkajian dan Pengembangan Teknologi Pertanian 22, 15 (2019a)

13. D. A. A. Elisabeth, S. Mutmaidah, A. Harsono, Proceedings of the 6th International Conference on Sustainable Agriculture, Food and Energy. IOP Conf. Series: Earth and Environmental Science 347 (2019) 012114 (2019b) 
14. Istriningsih, Y. A. Dewi, Asian Journal of Agriculture and Development 12, 33 (2015)

15. A. Habib, R. Affandi, M. R. Siregar, IOSR Agriculture and Veterinary Science (IOSRJAVS) 7, 53 (2019)

16. M. Supartama, M. Antara, R. A. Rauf, e-J. Agrotekbis 1, 166 (2013)

17. K. S. Indraningsih, Forum Penelitian Agro Ekonomi 35, 107 (2017)

18. S. Nuryanti, D. K. S. Swastika, Forum Penelitian Agro Ekonomi 29, 115 (2011)

19. The National Standardization Agency of Indonesia [BSN], National Standard of Indonesian for soybean (SNI 01-3922-1995), in The National Standardization Agency of Indonesia, Jakarta, Indonesia (1995)

20. Koesrini, K. Anwar, E. Berlian, Berita Biologi 14, 155 (2015) 